בب د د بـ العزيز يوسف الكندري

نشوز الزوجة والأحكام المتعلقة به

وأثره على النفقة في الفقه الإسلامي

وقانون الأحوال الشخصية الكويتي

د. • عبد العزيز يوسف الكندري (")

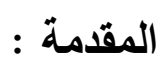

الحمد لله رب العالمين، و الصلاة و السلام على أشرف المرسلين سيدنا

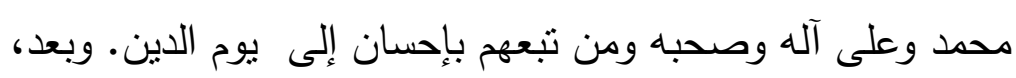

إنه مما لا يخفى أن من مقاصد الثريعة الإسلامية قسام الأسرة والمحافظة عليها، لأنها هي أساس بناء المجتمع، وركنه الأساسي، وتقوم هذه الأسرة أساسا على الزوجين، فإذا صلح الزوجان صلحت الأسرة وينعكس ذلك على المجتمع، وإذا فسدت العلاقة بينهما فسدت الأسرة، وانعكس ذلك سلباً على المجتمع.

لللك اهتم الإسلام بالعلاقة بين الزوجية أيما اهتمام وأقام التشريعات

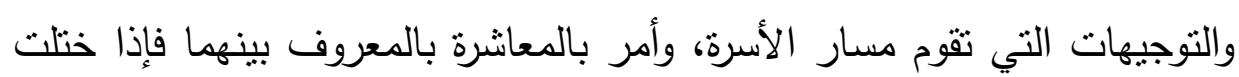
هذه العشرة أمر الثارع الحكيم بالإصلاح محافظة على لقباء الأسرة. ومن هذه الأمور التي تتخر في كيان الأسرة نشوز الزوجة.

وسنحاول في هذا البحث تسليط الضوء على بعض الأحكام التي تتعلق به،

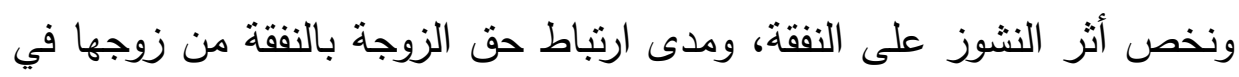
حال كانت ناشزة أو لا تسنطيع القيام بالواجبات الزوجية. 


\section{نشوز الزوجة}

ومدى نوافق القانون الكويتي مع الفقه الإسلامي في هذا الثأن.

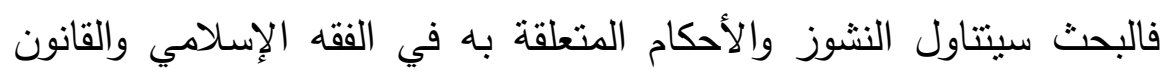
الكويتي، وسيركز على حق الزوجة الناثز في النفقة، ومن ثم نذكر الأحكام المتعلقة بالنشوز إجمالاً. على النحو النالي: * المبحث الأول: مفهوم النشوز وحكمه وما يكون النشوز به وفيه ثلاثة أفرع: الفرع الأول: التعريفات لغة، وفي اصطلاح الفقهاء، وفي القانون الكويتي. الفرع الثناني: حكم نشوز الزوجة.

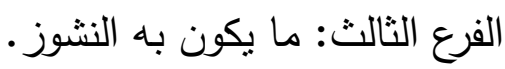

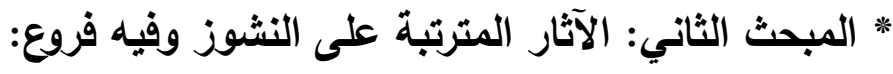
الفرع الأول: أثز النشوز على النفقة. الفرع الثاني: أثز النشوز في مدة الإيلاء. الفرع الثالث: أثز النشوز في قسم الزواج. الفرع الرابع: تأديب الزوجة. الفرع الخامس: التحكيم بين الزوجين. ونشرع الآن بتقصيل ذلك مستعينين بالله.

* * 
בب د د عبد العزيز يوسف الكندري

المبحث الأول

مفهوم النشوز وحكمه وما يكون النشوز به

الفرع الأول: التعاريف

النشوز لغة - النة

النَتْزْ : بالحركة والسكون المكان المرتفع والجمع، والنَتَزَ بفتحتين المرتفع من

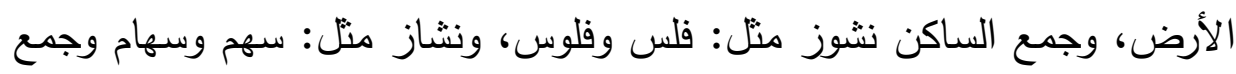

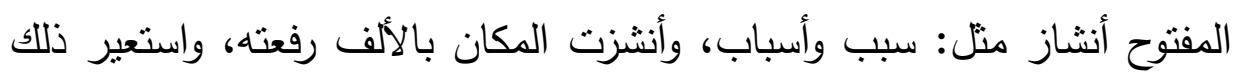

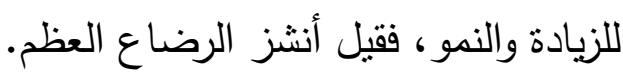

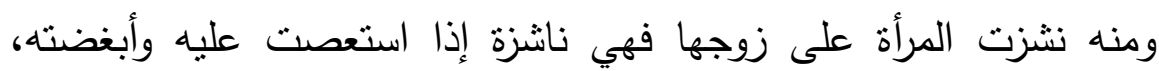

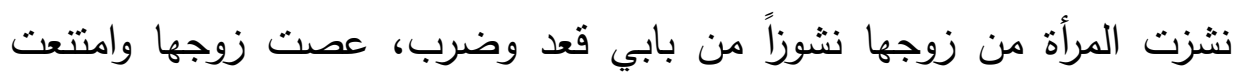
عليه. وفي القرآن الكريم \}وإن امرأة خافت من بعلها نشوزا أو إعراضا\{(') وأصله الارتفاع يقال نشز من مكانه نشوزا. وعن الزجاج النشوز يكون من الزوجين وهو كراهة كل واحد منهما

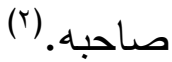

\section{النشوز في اصطلاح الفقهاء}

عرف الحنفية النشوز : أن تمنع نفسها من الزوج بغير حق خارجةً من منزله،

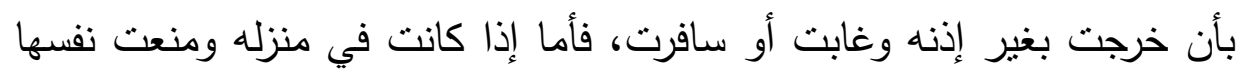

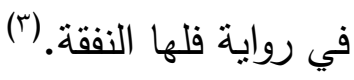


وعند المالكية: المرأة إذا خرجت من محل طاعة زوجها بغير إذنه ولم يقدر

على عودها إلى محل طاعته لا بنفسه ولا بالحاكم. (')

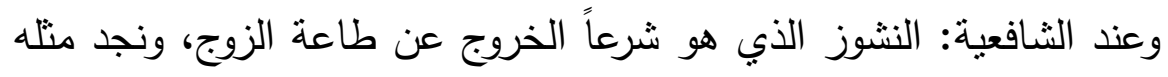

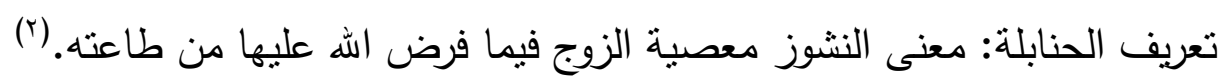

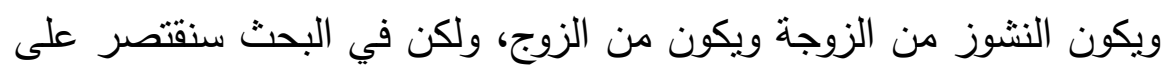

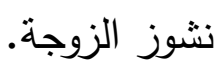

\section{تعريف النشوز في القانون الكويتي لتروني}

ذكر القانون الكويتي في المادة NV من قانون الأحوال الثخصية والمذكرة

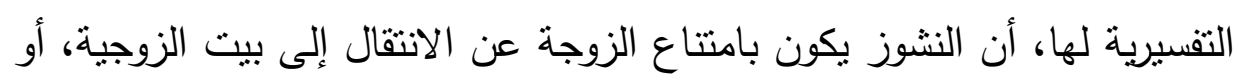

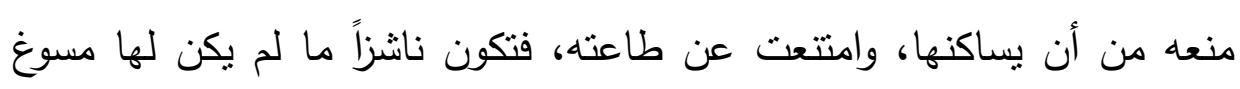

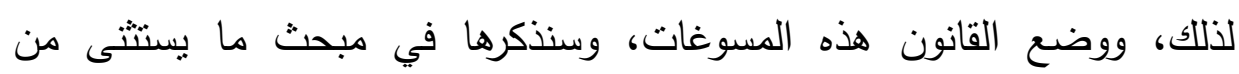
(r) النشوز

\section{الفرع الثاني: حكم نشوز الزوجة}

اتفق الفقهاء على حرمة نشوز المرأة على زوجها، واستدلوا على ذلك بأدلة منها

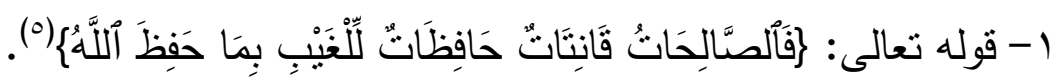

$$
\begin{aligned}
& \text { (1) شرح مختصر خليل للخرشي (ع/(19) (1). }
\end{aligned}
$$

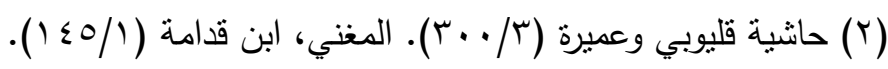

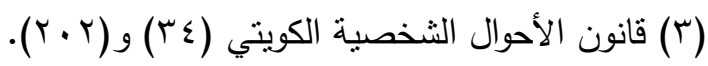

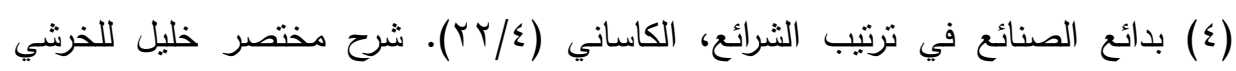

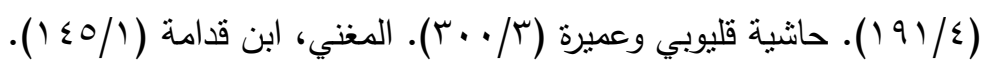

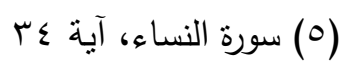




\section{د. د عبد العزيز يوسف الكندري}

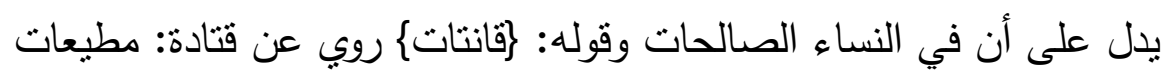
لله تعالى ولأزواجهن وأصل القنوت مداومة الطاعة ومنه القنوت في الوتر لطول (') (القيام. (1)

فًَالصَّلِحَحَنُ\{ أي من النساء $\}$

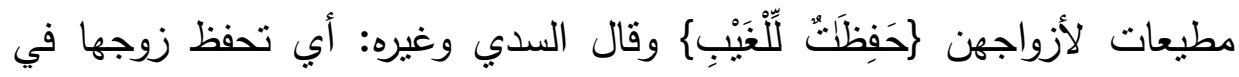
غييته في نفسها وماله. (r) r-وقوله تعالى: كإلا أن يأنتين بفاحشة مبينة\{.(r) وقال الضحاك: الفاحشة

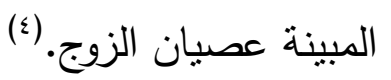
ب- عن الحصين بن محصن - رضي الله عنه - أن عمة له أتت النبي - صلى الله عليه وسلم - في حاجة ففرغت من حاجتها فقال لها النبي صلى الله عليه وسلم - "أذات زوج أنت؟" قالت: نعم "قال: كيف أنت له؟" قالت: ما آلوه إلا ما عجزت عنه قال:" فانظري أين أنت منه فإنما هو جنتلك

$$
\text { ونارك". (0) }
$$

؟- عن عبد الرحمن بن عوف - رضي الله عنه - قال: قال رسول الله - صلى الله عليه وسلم - "إذا صلت المرأة خمسها وصامت شهرها وحفظت فرجها

وأطاعت زوجها قيل لها ادخلي الجنة من أي أبواب الجنة شئت".( ) ه- عن أبي هريرة - رضي الله عنه - عن النبي - صلى الله عليه وسلم - قال: "لو كنت آمراً أحداً أن يسجد لأحد لأمرت المرأة أن تسجد لزوجها".

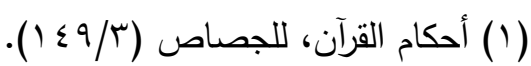

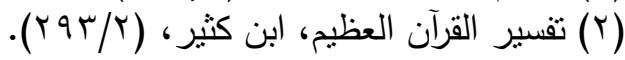

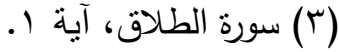

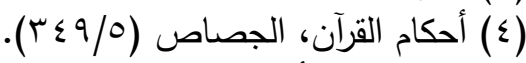

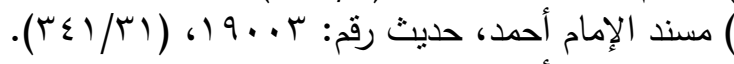

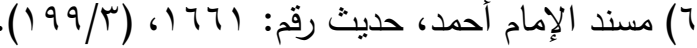

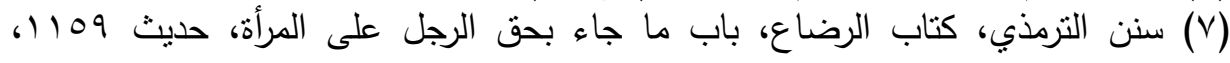
. ( $104 / \mathrm{r})$ 
1- عن أبي هريرة - رضي الله عنه - عن النبي - صلى الله عليه وسلم - قال:

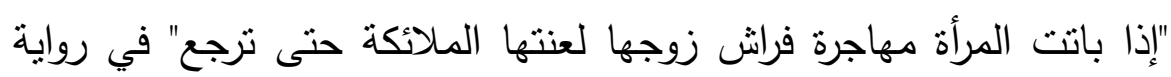

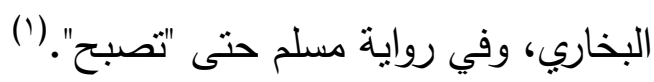
- V عن أبي هريرة - رضي اله عنه - عن النبي - صلى الله عليه وسلم - قال: "إذا دعا الرجل امرأته إلى فراثه فأبت أن تجيئ لعنتها الملائكة حتى الهى

ᄉ- عن ابن عباس - رضي الله عنهما - قال رسول الله - صلى الله عليه وسلم

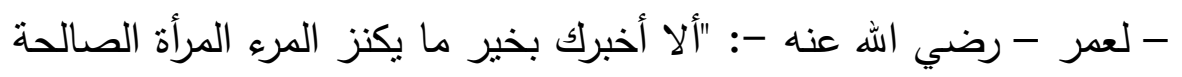

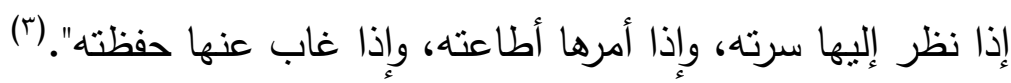
الفرع الثالث: ما يكون به النشوز اختلف الفقهاء فيما يكون به نشوز المرأة وسنذكره الأحكام المتعلقة في

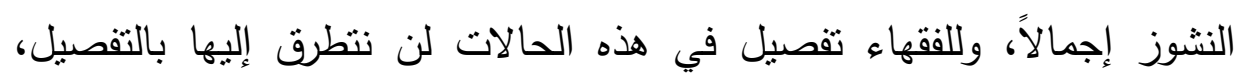

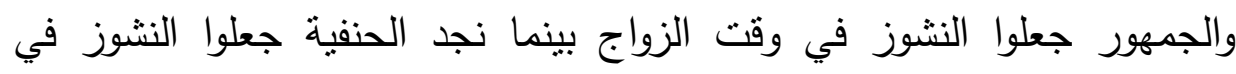

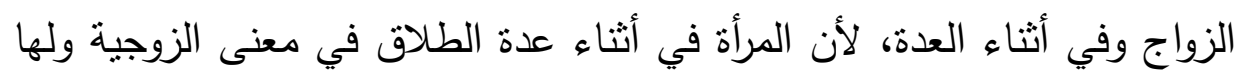
نفقة. (\&) ونذكر بعض صور النشوز عند الفقهاء ثم القانون الكويتي. من صور النشوز عند الفقهاء: 1- منع الزوج من الوطء والاستمتاع من غير مانع شرعي.

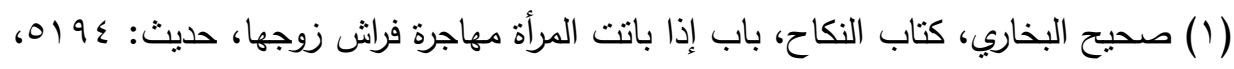

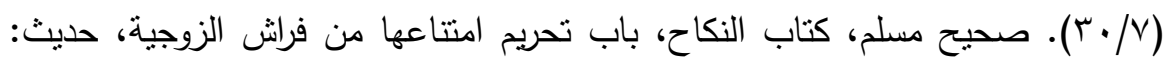

$$
\text { . (1.09/Y)، (1) (r) }
$$

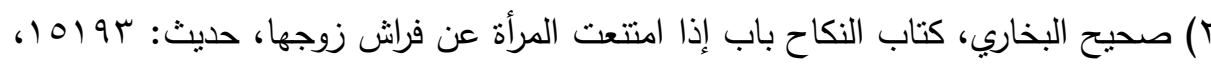

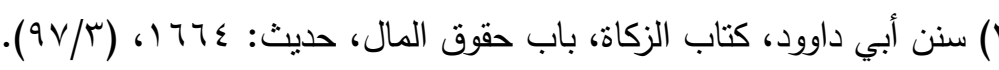

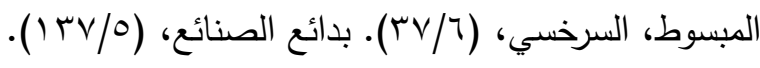




\section{د · · عبد العزيز يوسف الكندري}

ץ- خروجها من البيت من غير إذن زوجها وهي تعلم بعدم رضاه، وليس الخروج واجباً عليها.

r- نرك حقوق الله عليه كالاغنسال والصلاة وصوم رمضان.

$$
\text { ع- إغلاق الباب دونه. }
$$

0- أن تخونه في نفسها وماله.

7- إذا سافرت بغير إذنه ولم يكن السفر واجبا.

V- وبكون النشوز بالقول بأن تجيب زوجها بخشونة وهو ليس من عادتها وكانت

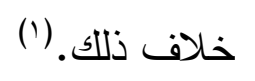

وأخذ القانون بهذه الأسباب للنشوز في المادة NV ومذكرتها التفسيرية، وقيد ذلك في الفقرة ب: لا يثبت نشوز الزوجة إلا بامتتاعها عن تتفيذ الحكم النهائي

للطاعة. (r)

\section{يستثى من النشوز:}

واستثنى الققهاء بعض الحالات التي لا تعتبر نشوزاً مع أن ظاهرها خروج

الزوجة عن طاعة زوجها، وكذلك القانون الكوبتي، ومنها: 1- خروج الزوجة إلى القاضي لطلب حق من الزوج أو جلب نفقة إذا كان الزوج

معسراً عليها.

r- خروجها للاستفتاء إذا لم يكن الزوج فقيها.

r- إذا خرجت لحاجت البيت الضرورية ، أو حاجتها الثخصية. ع- الخوف من تهدم المنزل، أو جلاء من حولها من الجيران.

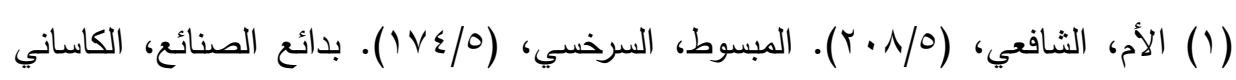

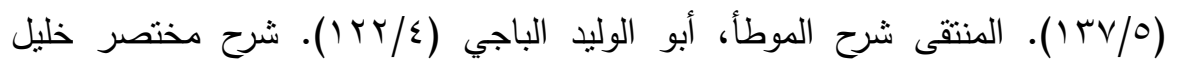

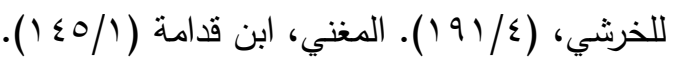

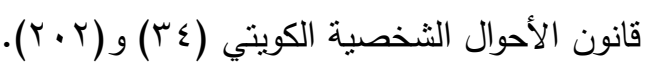


0- عدم تمكين الزوج من الوطء لعيب منفر في الزوج من مرض معدي أو رائحة لا يمكن تحماها.

צ- إيذاء الزوجة للزوج باللسان، فلا تعتبر ناشزاً ولكن تأثن. V- يستثى من السفر بغير إذن لو ارتحلت لخراب البلد.

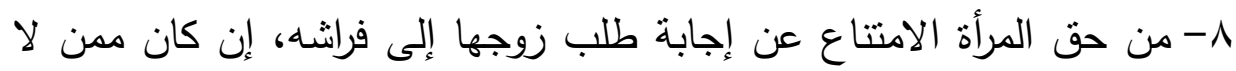
يستتز عن الناس حين الجماع، ولا تصير ناشزا بهذا الامتتاع.

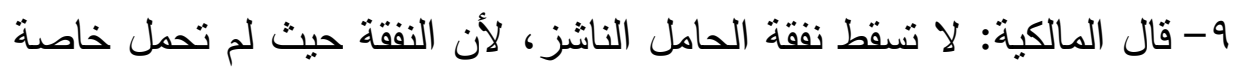

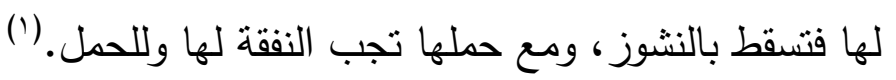

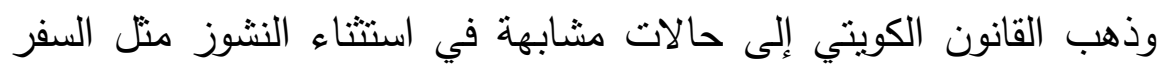

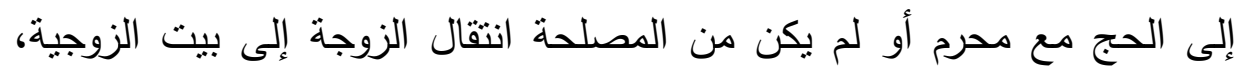

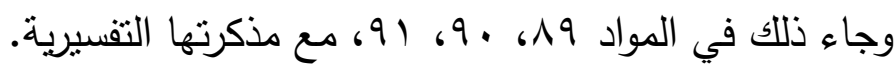

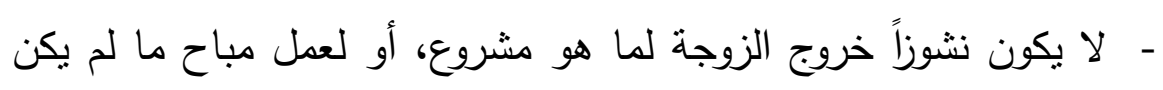
عملها منافياً لمصلحة الأسرة. - على الزوجة أن تتنقل مع زوجها إلا إذا رأت المحكمة أن المصلحة في

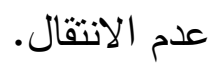
- للزوجة أن تسافر مع محرم لأداء فريضة الحج، ولو لم يأذن الزوج، وتستمر لها نفقة الحضر مدة السفر.

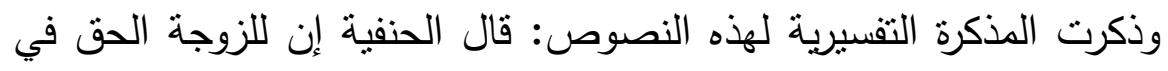

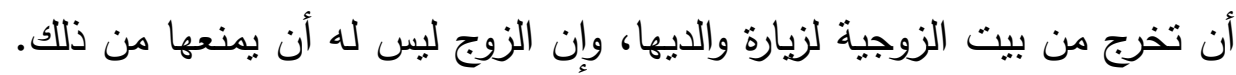

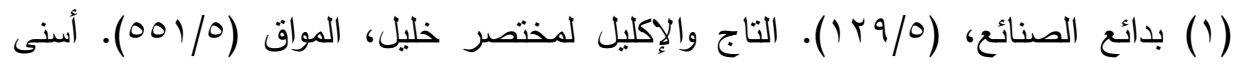

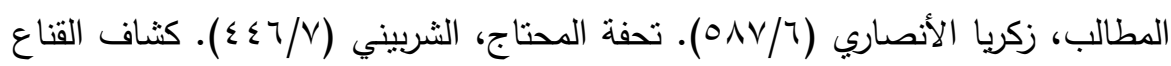

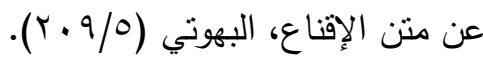




\section{د. · عبد العزيز يوسف الكندري بـ}

وقالوا: إن لها الحق أن تقوم بخدمة المريض من أبويها، وعليها تعهده بقر احتياجه ولو كان غير مسلم، وإن أبى الزوج.

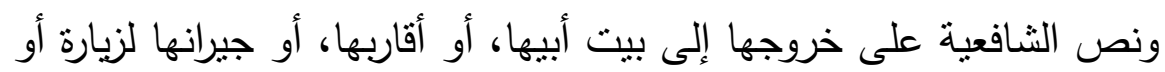

عيادة أو تعزية، وإلى القاضي لطلب الحق منه، وخروجها لحوائجها التي يقتضي العرف خروج متلها لها لتعود عن قرب وخروجها لإشراف البيت على الانهدام، أو أو ألى

بإكراهها على الخروج، أو إذا أعسر بالنفقة سواء أرضيت بإعساره أم لا. لا. وبناء على هذا، وعلى العرف صيخت هذه المادة، ولوحظ فيها أنه إذا طرأت

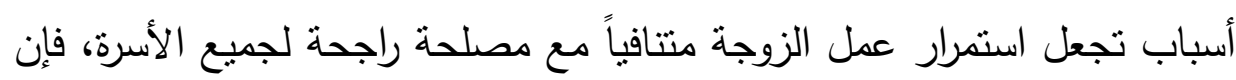
خروج الزوجة للعمل في هذه الحال يعتبر نشوزاً.(') مسألة خروج الزوجة للعمل:

إذا كان العمل بإذن الزوج ورضاه فلا تكون ناشزاً، وتجب النفقة عليها، أما

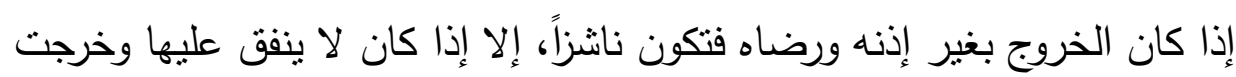

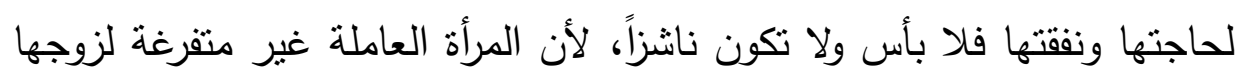
فتتقص من حقه، وبهذا ذهب جمهور الفقهاء من الحنفية والمالكية والثافعية والحنابلة، وبهذا صرح الحنفية بقولهح : لو تزوج من المحترفات التي تكون بالنهار

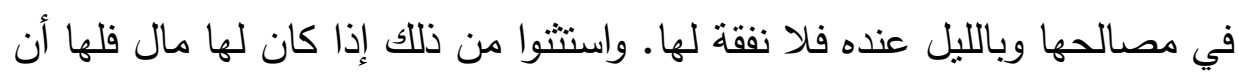
تتاجر به مع غيرها، كأن نشاركه أو تدفعه مضاربة دون إذن من أحد وحتى زوجها ولا يعتبر نشوزاً لأن لها ذمة مالية مستقلة وهي حرة بمالها، وصرح بذلك الك المالكية بقولهم: دفعها مالا لمن يتجر فيه ببعض ربحه، فلا يحجر علبها فيه

(r) اتفاقاً

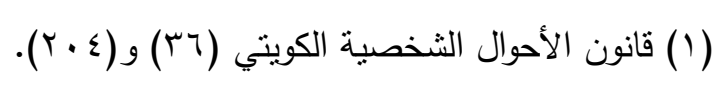

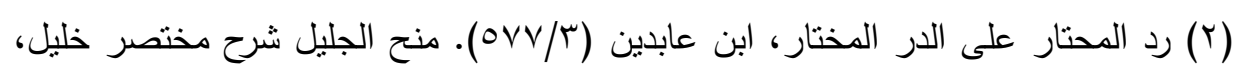

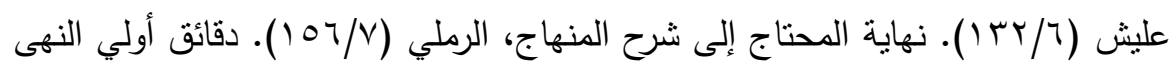

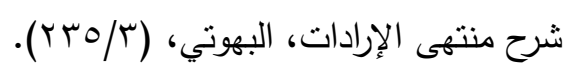




\section{نثوز الزوجة}

ولكن القانون ذهب في منحى آخر فجاء في المادة 19 19

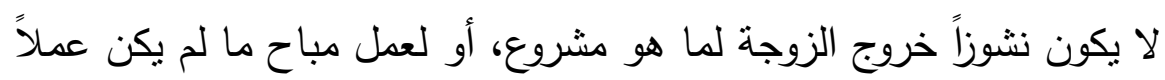

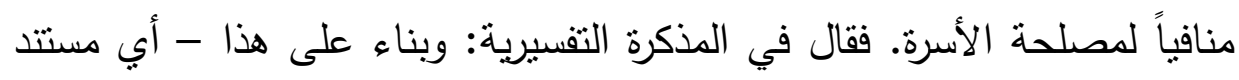

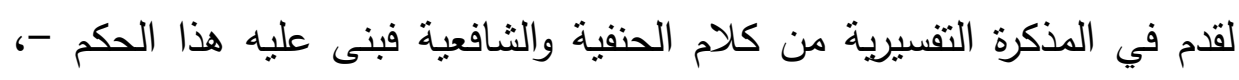

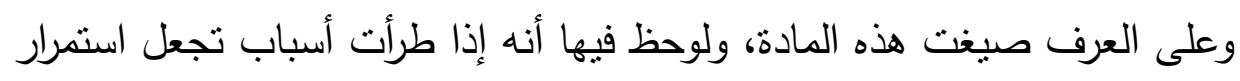

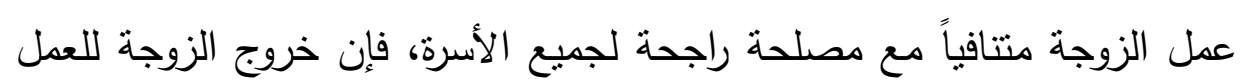
في هذه الحال يعتبر نشوزاً.(') والذي يتبين أن الأفضل للمرأة المكوث في بيتها ولا تخرج للعمل إلا للحاجة

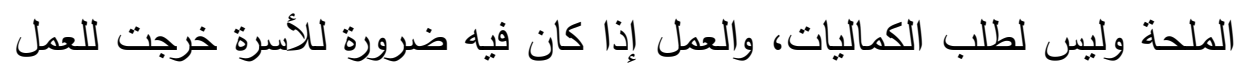

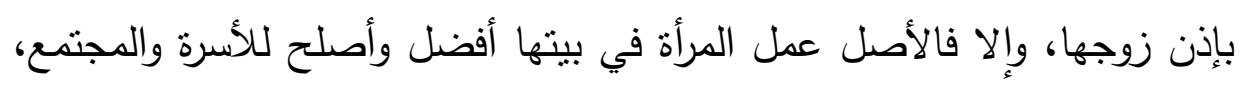

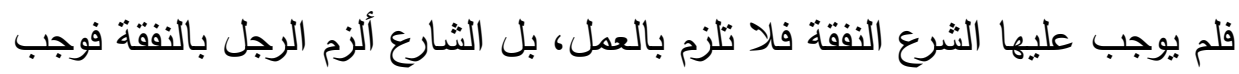
عليه العمل. 


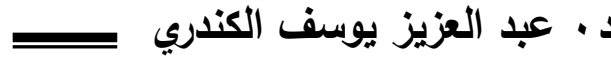

المبحث الثاني

\section{الآثار المترتبة على النشوز}

الفرع الأول: أثر النثوز على النفقة

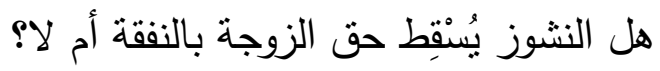

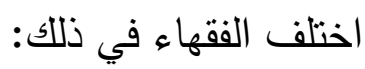

الرأي الأول: - الرأ

ذهب الجمهور من الحنفية والمالكية على المشهور والثافعية والحنابلة، إلى

أن النشوز يسقط حق النفقة والسكنى.

قال الكاساني: ولا نفقة للناشزة لفوات التسليم بمعنى من جهنها وهو النشوز ،

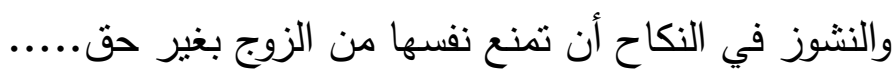
واستخلوا على ذلك:

- لأنها إنما نستوجب النفقة بنسليمها نفسها إلى الزوج وتفريغها نفسها

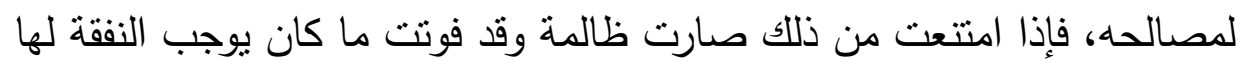
باعتباره فلا نفقة لها. - أنها تجب مقابل نسليمها نفسها للزوج بدليل أن النفقة لا تجب قبل ذلك.

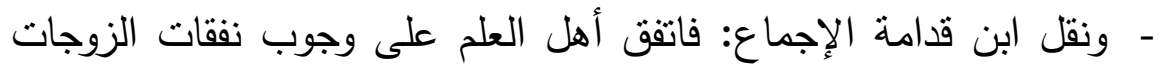
على أزواجهن، إذا كانوا بالغين، إلا النانشز منهن. ولكن هذا الإجماع خرج عنه كما سنرى. واستثىى المالكية المرأة الحامل، المطلقة طلاقاً رجعياً إذا خرجت من غير الاجئ

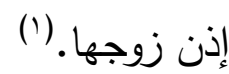

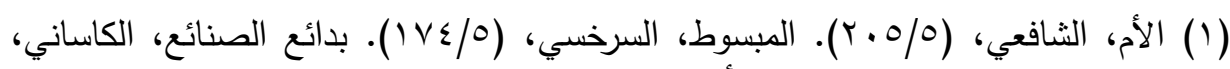

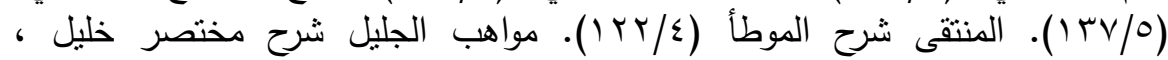

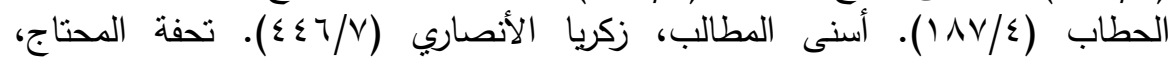

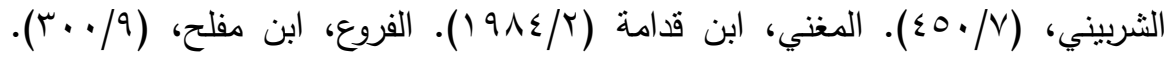

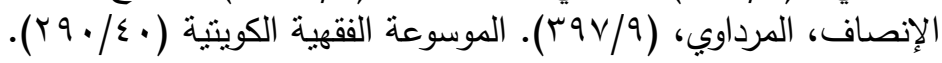


وبهذا أخذ القانون الكويتي كما نص في المادة N (إذا امتتعت الزوجة عن المنه

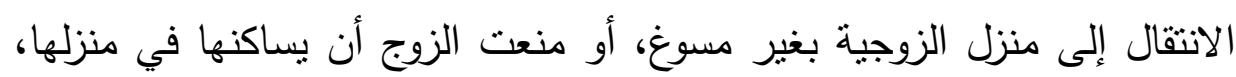

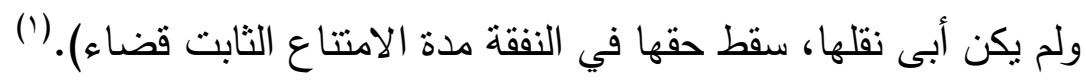

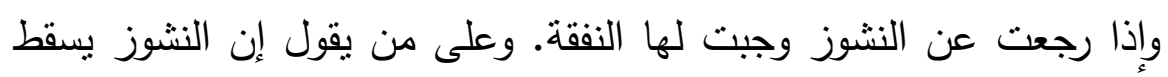

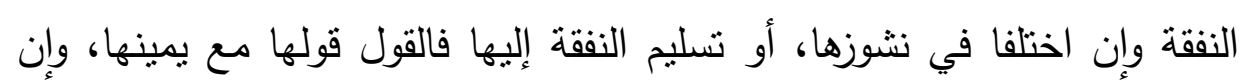

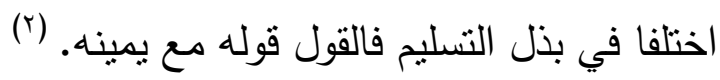

الرأي الثاني: ذهب بعض المالكية وابن حزم، إلى أن النفقة لا نسقط فينه

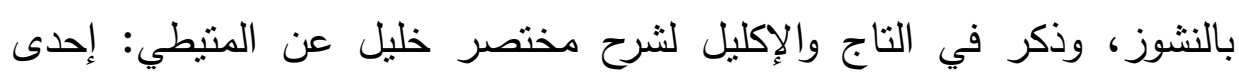

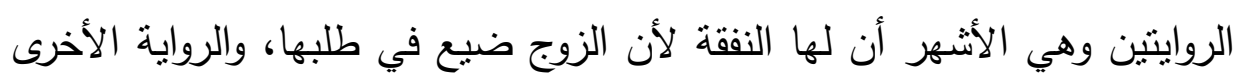

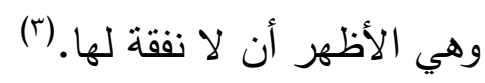
واستخلوا على ذلك:

- بأن النشوز لا يسقط المهر وكذلك النفقة.

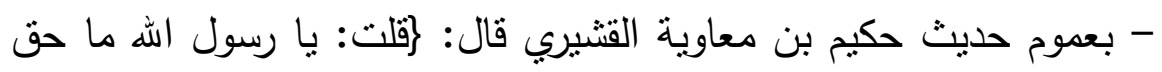

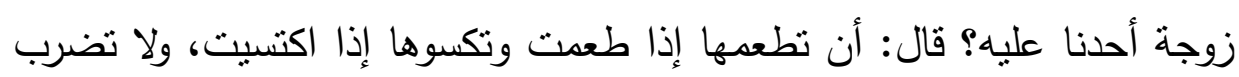

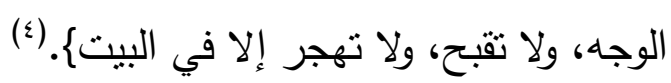

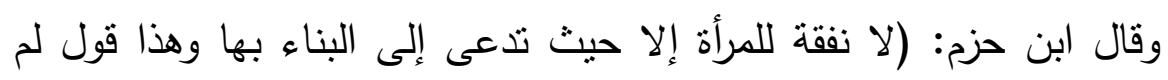

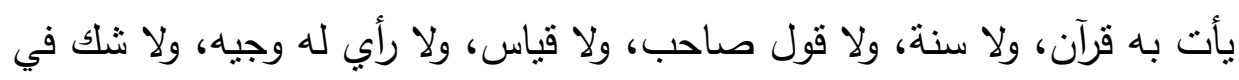

$$
\text { (1) (بانون الأحوال الثخصبة الكويتي (ع ب). }
$$

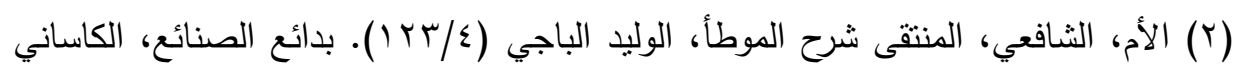

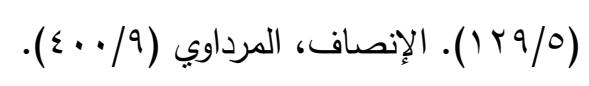

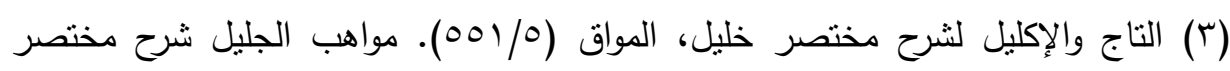

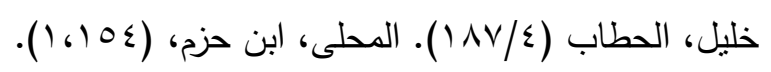

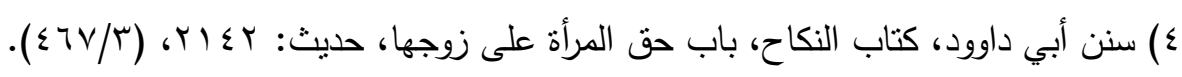




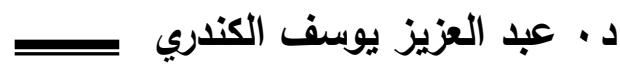

أن الله - عز وجل - لو أراد استثناء الصغيرة والناشز لما أغلل ذلك حتى يبينه لله غيره، حاش الله من ذلك. وعن ابن عمر - رضي الله عنه - قال: " كتب عمر بن الخطاب إلى أمراء الأجناد أن انظروا من طالت غييته أن يبعثوا نفقة أو يرجعوا أو يفارقوا فإن فارق فإن عليه نفقة ما فارق من بوم غاب "، ولم يخص عمر ناشزاً من غيرها. ومن طريق شعبة سألت الحكم بن عتيبة عن امرأة خرجت من بيت زوجها غاضبة هل لها نفقة؟ قال: نعم - وقال سفيان الثثري: النفقة واجبة للصغيرة من حين العقد عليها. وما نعلم لعمر في هذا مخالفاً من الصحابة - رضي الله عنهم - ولا يحفظ منع الناشز من النفقة عن أحد من الصحابة. إنما هو شيء روي عن النخعي، والشعبي، وحماد بن أبي سليمان،

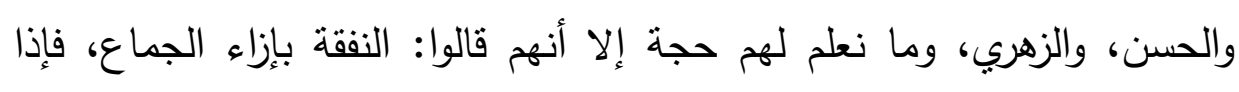
منعت الجماع منعت النفقة. وهذه حجة أفقر إلى ما يصححها مما راموا تصحيحها به، وقد كذبوا في ذللك، ما النفقة والكسوة إلا بإزاء الزوجية، فإذا وجدت الزوجية فالنفقة والكسوة واجبتان.

والعجب كله استحلالهم ظلم الناشز في منعها حقها من أجل ظلمها للزوج في منع حقه، وهذا هو الظلم بعينه، والباطل صراحاً. والعجب كله أن الحنفيين لا يجيزون لمن ظلمه إنسان فأخذ له مالا فقدر على الانتصاف من مال يجده لظالمه أن ينتصف، رأوا منع الناشز النفقة، لئه والكسوة، ولا يدرى لماذا؟ 
وقد تتاقضوا في حجتهم المذكورة فرأوا النفقة للمريضة التي لا يمكن وطؤها،

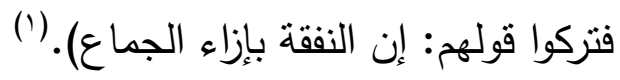

ورأي ابن حزم - رحمه الله - بيتحق النظر، وفي استخلاله قوة وحجة على يلى

كما بينا.

ومن الأفضل للأسرة أن لا تمنع المرأة النانز من النفقة، خاصة إذا كانت

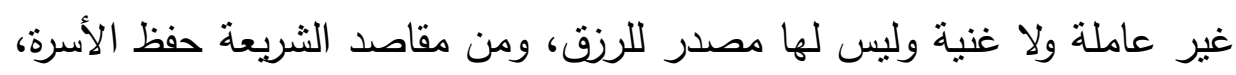

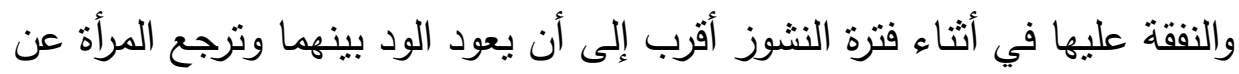

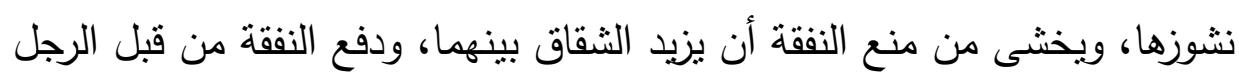

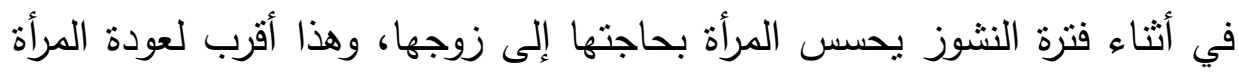
عن نشوزها، وأحفظ للأسرة.

الفرع الثاني: أثر النشوز في مدة الإيلاء:

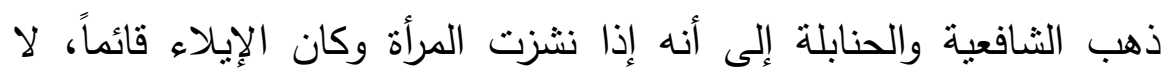

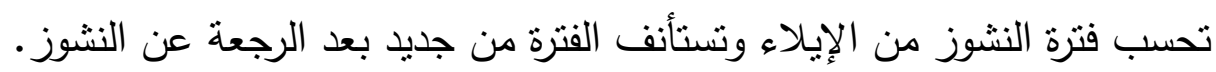

$$
\text { ولا يبدأ الإيلاء من باب أولى في مدة النشوز . }
$$

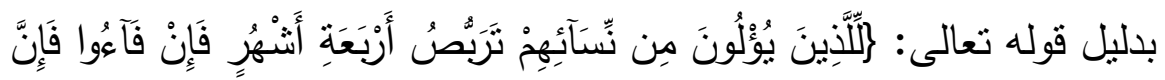

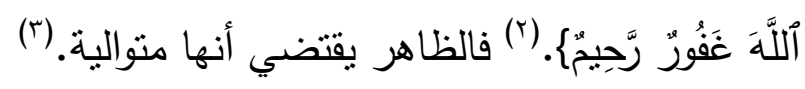

$$
\begin{aligned}
& \text { (1) المحلى، ابن حزم (1 (1/ (1) 1) ). }
\end{aligned}
$$

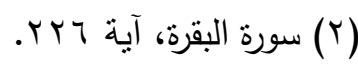

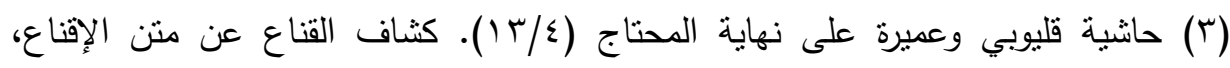

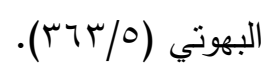


الفرع الثالث: أثز النشوز في قسم الزواج

النشوز يسقط حق المرأة في القسم مع الزوجات الأخريات، لأن بنشوزها

رضيت بإسقاط حقها من القسم. (')

وذكر الإمام الثافعي - رحمه الله - في هذا الموضوع: قد قال الله -عز

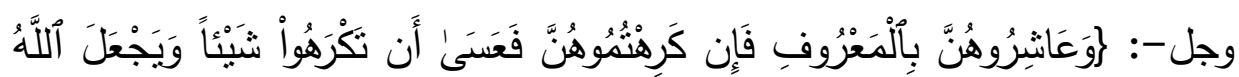

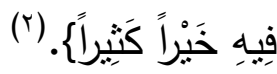

فيحل للرجل حبس المرأة على ترلك بعض القسم لها أو كله ما طابت به

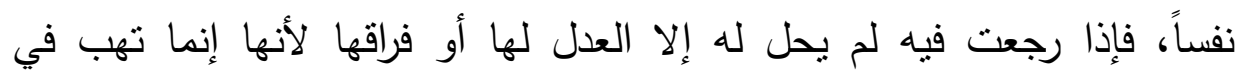
المستأنف ما لم يجب لها فما أقامت على هبته حل وإذا رجعت في هبته حل ما

مضى بالهبة ولم يحل ما يستقبل إلا بتجديد الهبة له.

وإذا وهبت له ذلك فأقام عند امرأة له أياماً ثخ رجعت استأنف العدل عليها

$$
\text { وحل لله ما مضى قبل رجوعها }
$$

فأن رجعت ولا يعلم بالرجوع فأقام على ما حللته منه ثم علم أن قد رجعت

استأنف العدل من يوم علم ولا بأس عليه فيما مضى، وإن قال: لا أفارقها ولا

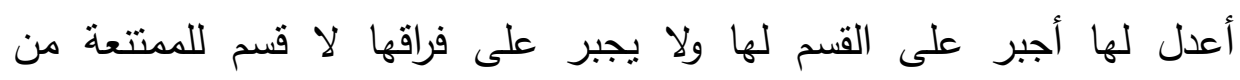

زوجها. (r) (ع)

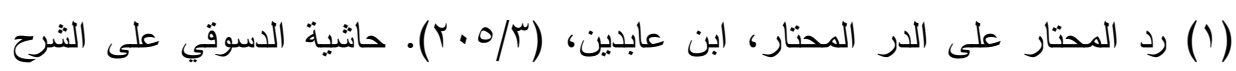

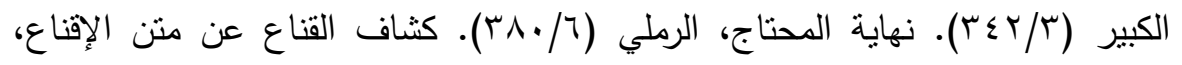

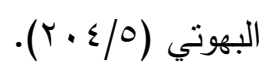

(Y) (Y) سورة النساء، آية 19.

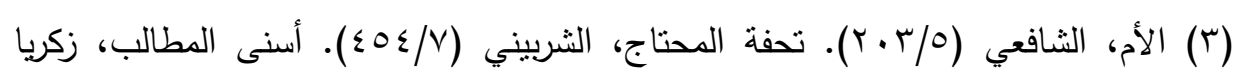

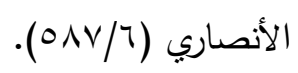




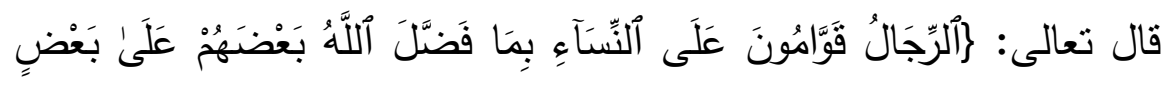

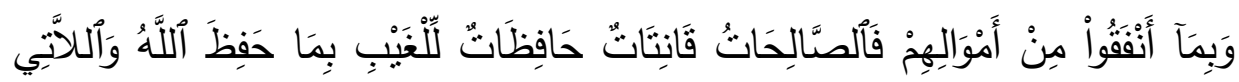

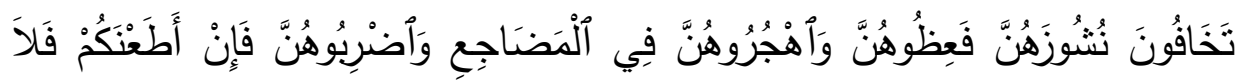

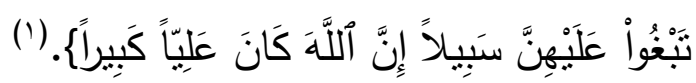

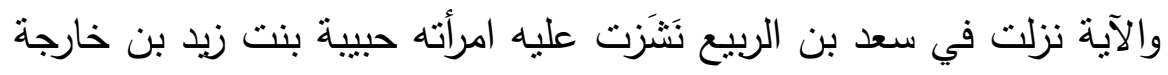

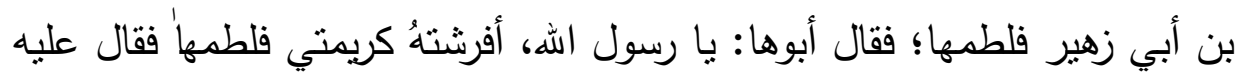

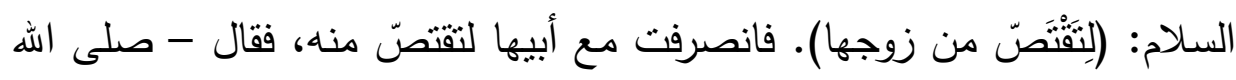

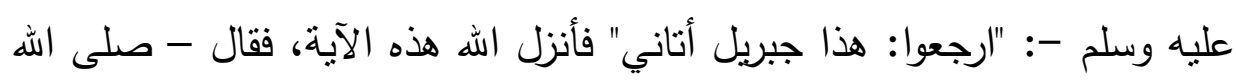

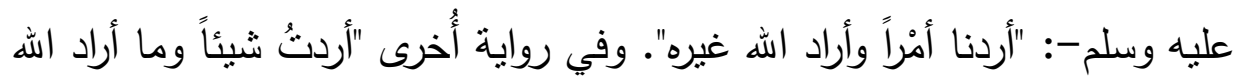

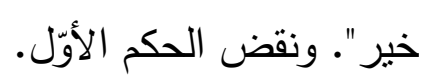

ودلت هذه الآية على تأديب الرجال نساءهم، فإذا حفظن حقوق الرجال فلا

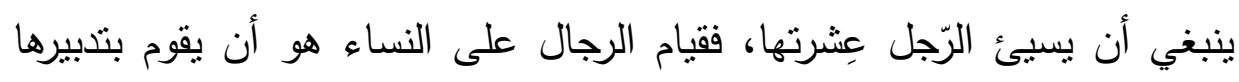

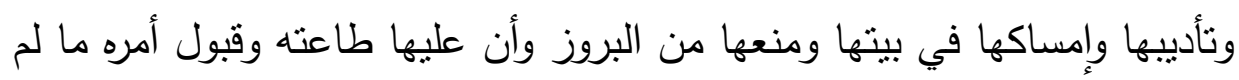

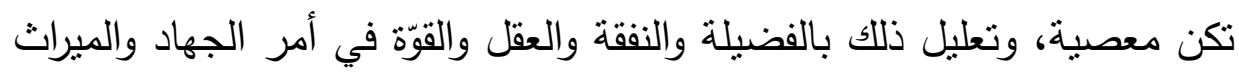

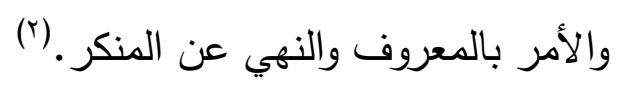
ما يكون به التأديب

اتفق الفقهاء على أن للزوج أن يؤدب زوجته إما بالوعظ أو بالهجر أو

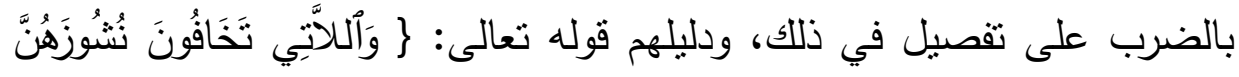


ב

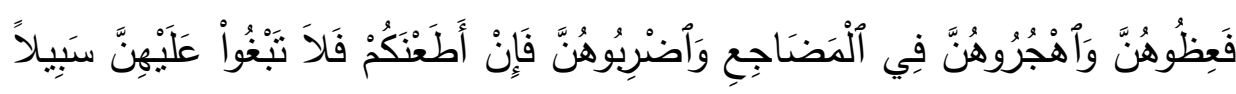
(1). إنَّ أللَّةَ كَانَ عَلِيّاً كَبِيراً

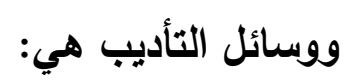
1-الوعظ:

ويكون بالقول الحسن الجميل، ويستحب التلطف معها. قال ابن

كثير :ففظوهن\{ يعني خوفوهن بالله وبعقابه. (r) فيعظها أولاً على الرفق واللين بأن يقول لها: كوني دن الصالحات القانتات الحافظات للغيب ولا تكوني من كذا وكذا، فلعل تقبل الموعظة، فنترك بكرئ النشوز ، فإن نجعت فيها الموعظة، ورجعت إلى الفراش وإلا هجرها.(r)

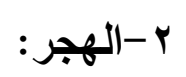

وإذا لم يفد الوعظ انتقل إلى الهجر، واختلف الفقهاء في كيفية الهجر ومدته. النوع الأول: أن يهجرها في الفراش ولا يضاجعها، وذهب إلى ذلك الحنفية والمالكية وقول عند الثافعية وقول عند الحنابلة، وهو قول سعيد بن جبير: ومجاهد والثعبي وإبراهيم النخعي. واختلفوا في مدته إلى: - الحنفية قالوا إلى وقت ما تغلب عليها الثهوة. - - أما المالكية فقالوا شهراً. - والثافعية والحنابلة ذهبوا إلى عدم تحديد المدة ولو بلغ سنين، حتى يصلح حالها. 
النوع الثاني: الهجران في الكلام وذهب إليه الثنافعية والحنابلة، وهو قول: ابن عباس وعكرمة والضحالك والسدي. - وجعلوا مدنه لا تزيد عن ثلاثة أيام لحديث أبي أيوب الأنصاري - رضي ولي الني

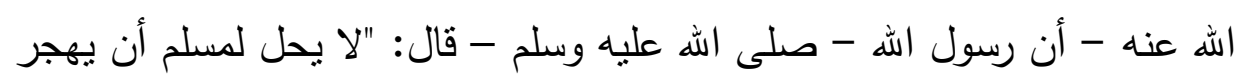

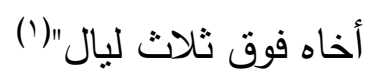

- وذهبوا في رأي آخر إلى الزيادة على ذلك لأن الحديث يستثى منه إذا

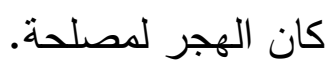
النوع الثالث: وقيل يهجرها بأن لا يكلمها في حال مضاجعته إياها لا أن

$$
\text { بترك جماعها ومضاجعتها.(؟) بالضرب: }
$$

الفقهاء متفقون على جواز ضرب الزوجة للنأديب. واشترطوا لذلك شروطاً

$$
\begin{aligned}
& \text { منها: } \\
& \text { 1 أن يكون الضرب غير مبرح ولا مدم. } \\
& \text { r- أن لا يكسر عظما ولا يشين جرحا. } \\
& \text { r- ولا يضرب الوجه والمهالك. } \\
& \text { ع- ولا يضربها أمام الناس ولكن يكون الضرب في البه البيت. } \\
& \text { ه- لا يكرر الضرب في نفس المكان لكي لا يترك فيه أثر. } \\
& \text { 7- ويتجنب الأماكن المستحسنة لكي لا يشوهها. }
\end{aligned}
$$

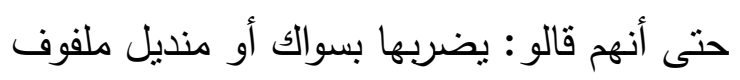

( (1) صحيح مسلم، كتاب البر والصلة، باب تحريم الهجر فوق ثلاث إلا لعذر شرعي، حديث:

$$
\text { . }
$$

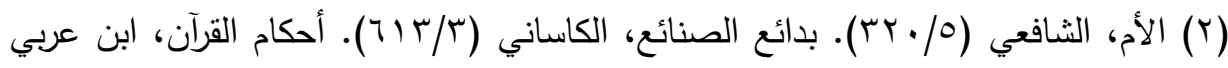

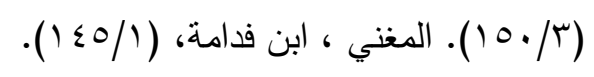




\section{دـ · · عبد العزيز يوسف الكندري}

وجماع ذللك في قول رسول الله - صلى اله عليه وسلم-: "فانقوا الهه في لئل

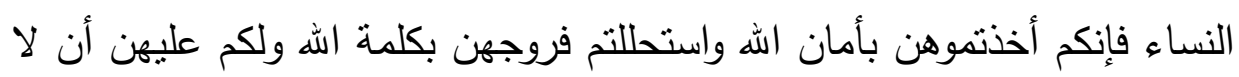

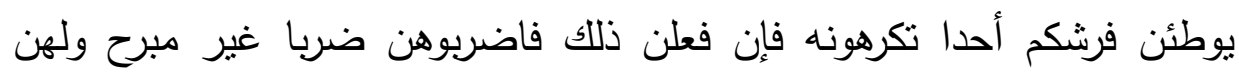
عليكم رزقهن وكسوتهن بالمعروف". (')

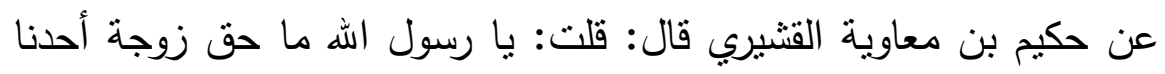

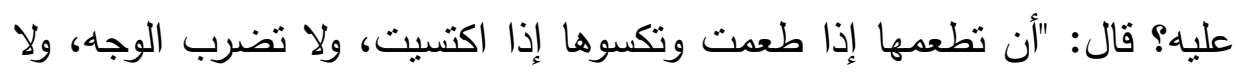

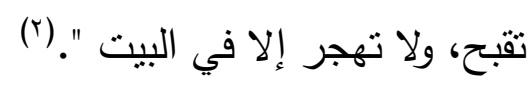
ومع ذلك كره العلماء الضرب لإذلاله للمرأة وهذا غير مستحب شرعاً ويدل

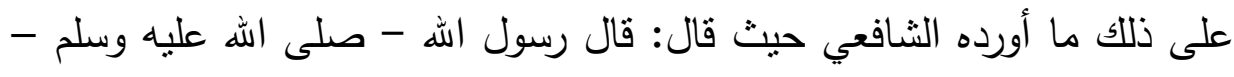

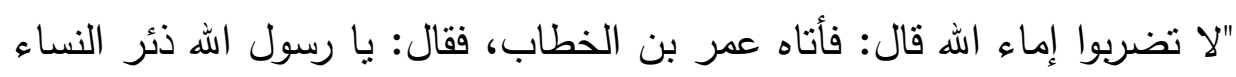

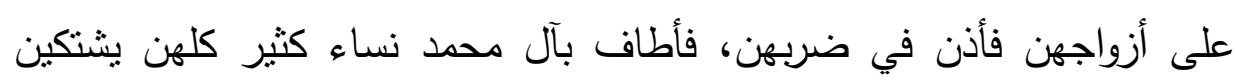

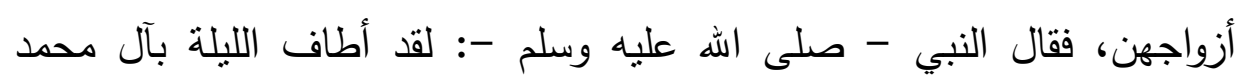

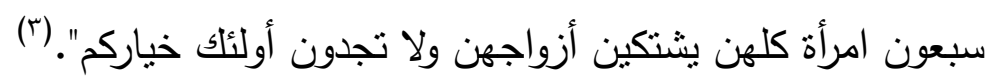

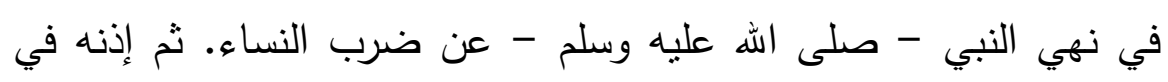
ضربهن وقوله - صلى الله عليه وسلم -: "لن يضرب خياركم" يشبه أن يكون -

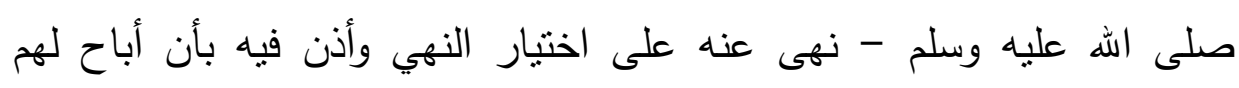

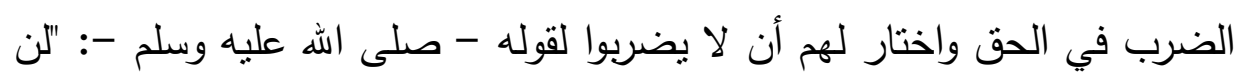

$$
\text { يضرب خياركم". }
$$

ويحتمل أن يكون قبل نزول الآية بضربهن ثم أذن لهم بعد نزولها بضربهن.

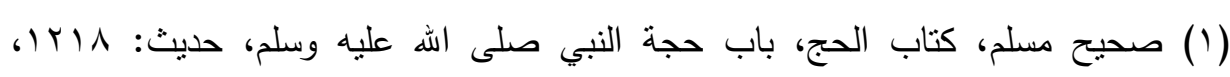

$$
\text { (^^т/r) }
$$

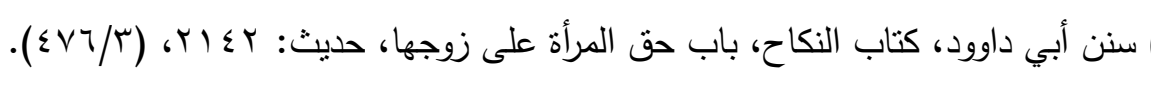

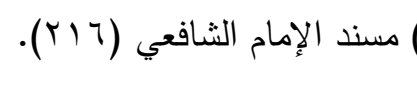


وفي قوله - صلى الله عليه وسلم -: "لن يضرب خياركم" دلالة على أن أن إنه

$$
\text { ضربهن مباح لا فرض أن يضربن. }
$$

وقال الثافعي - رحمه الله - في آخر كلامه: ونختار لله من ذللك ما اختار

رسول الهه - صلى اله علبه وسلم - فنحب للرجل أن لا يضرب امرأته في انبساط آلهار

لسانها عليه وما أثبه ذلك. (')

ونجد أن القانون قد صرح في مادة شي أنه لا يجوز تتفيذ حكم الطاعة جبراً

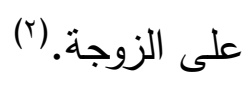

\section{الفرع الخامس: التحكيم بين الزوجين:}

وإذا احتدم الخلاف بين الزوجين، شرع الله دخول الحكمين ليصلحا بينهما.

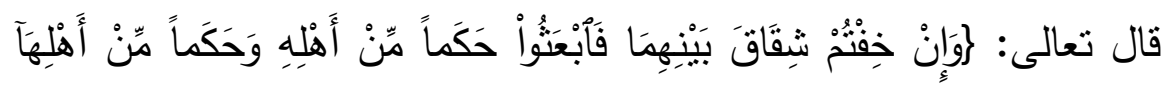

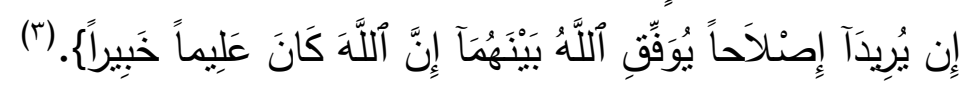

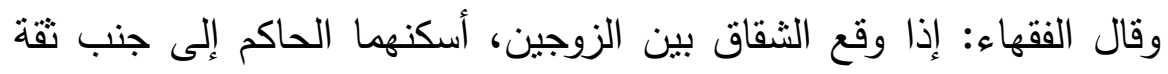

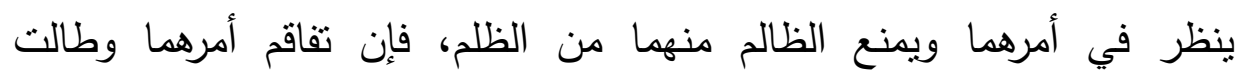
خصومتهما، بعث الحاكم ثقة من أهل المرأة وتثقة من قوم الرجل ليجتمعا فينظرا

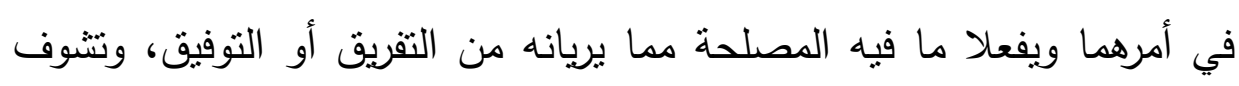

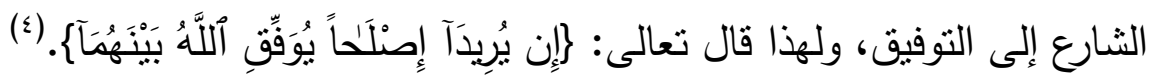

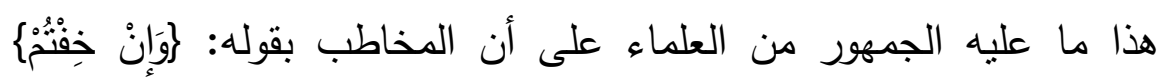

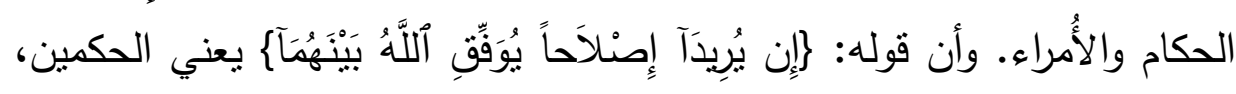

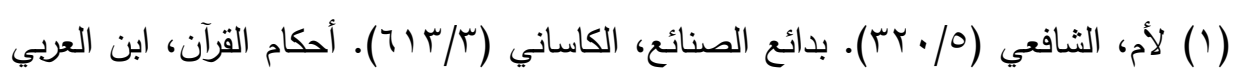

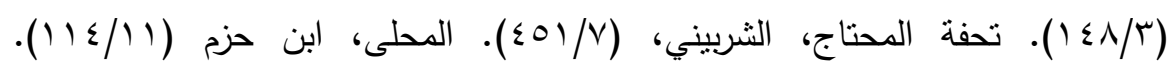

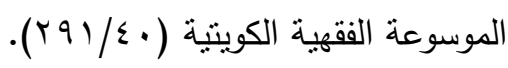

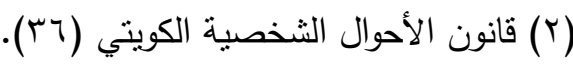

(ז) سورة النساء آية هب.

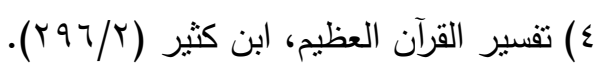




\section{د · · عبد العزيز يوسف الكندري}

في قول ابن عباس ومجاهد وغيرهما، أي إن يرد الحكمان إصلاحاً يُوفّق الله بين الزوجين.

وقيل: المراد الزوجان، أي إن يرد الزوجان إصلاحاً وصِدقاً فيما أخبرا به

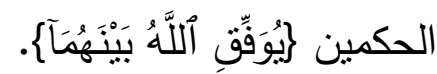

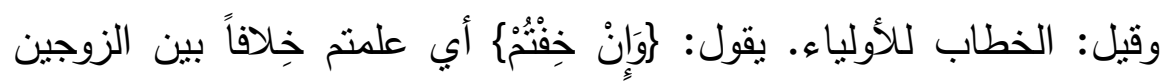

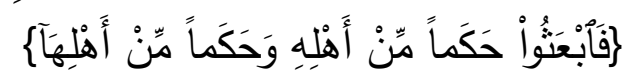

والحكمان لا يكونان إلا من أهل الرجل والمرأة؛ إذ هما أقعد بأحوال

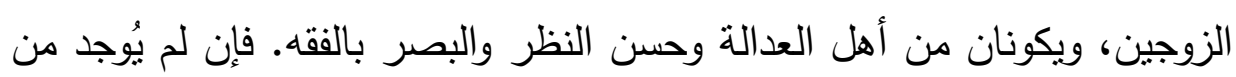
أهلهما من يصلح لذلك فيرسل من غيرهما عدلين عالمِين؛ وذلك إذا أشكل أمرهما

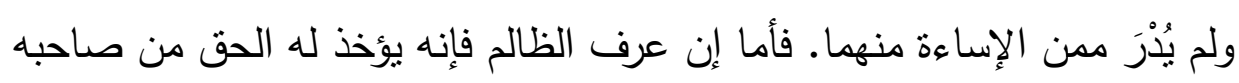
وبجبر على إزالة الضرر •

من ذلك ما روي أنه جاء رجل وامرأة إلى علي - رضي الله عنه - ومع كل واحد منهما فئام من الناس فأمرهم علي فبعثوا حكماً من أهله وحكما من أهلها ثم قال للحكمين: تدريان ما عليكما، عليكما إن رأيتما أن تجمعا أن تجمعا وإن أنيتما أن تفرقا أن تفرقا قالت المرأة رضيت بكتاب الهه بما علي فيه ولي، وقال الرجل أما الفرقة فلا. فقال علي - رضي الله عنه - كذبت والله حتى ثقر بمنل الذي أقرت 


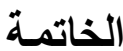

وبعد استعراض البحث من بعض جوانبه الفقهية والقانونية، نتوصل لما يلي: 1- أن كل من الفقه والقانون جعل نشوز الزوجة مخالفة تتحمل نتائجها الزوجة،

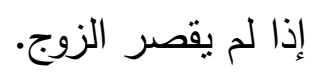

r- أن القانون الكويتي لم يخرج في أحكامه المتعلقة بالنشوز عن الفقه الإسلامي

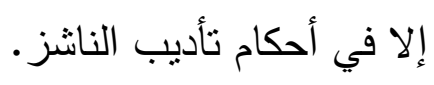

r-رغم أن القانون أخذ بحكم سقوط النفقة عن الناشز ووافق بذلك جمهور

$$
\text { الفقهاء، إلا أن رأي ابن حزم في عدم إسقاط النفقة رأي له وجاهة. }
$$

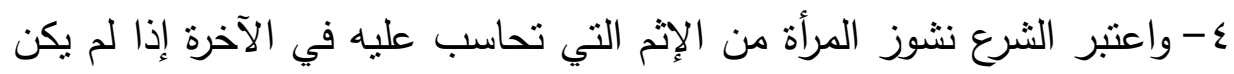

$$
\text { لها ذريعة شرعية. }
$$

0- رعى الثرع والقانون بعض الحالات التي لا يكون للمرأة في مخرج من النشوز

$$
\text { أو حالات تمنع تعسف الأزواج، واستثناها من النشوز . }
$$

צ- لحل مشكلة النشوز جعل الإسلام وسائل لذلك، تبدأ بالنصيحة وتنتهي

$$
\text { بالتحكيم. }
$$

V- مع جواز ضرب المرأة للتأديب جعل الفقهاء حدوداً لذللك، بل كرهه أكثرهم،

$$
\text { ومن الأولى تركه في الوقت الحاضر . }
$$

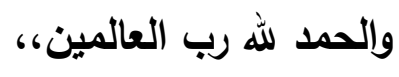


د. د عبد العزيز يوسف الكندري

\section{المراجع}

ترتيب المراجع على اسم الكتاب ترتيبا هجائيا، بعد القرآن الكريم.

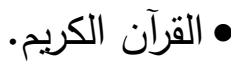

• أحكام القرآن، أحمد بن علي أبو بكر الرازي الجصاص الحنفي (المتوفى: •

$$
\text { ه. } 0
$$

• الأحوال الثخصية في التشربع الإسلامي مع بيان ما عليه العمل في المحاكم الكويتية - د. أحمد الغندور - كلية الحقوق والثريعة - جامعة الكويت -

• أسنى المطالب، زكريا بن محمد بن زكريا الأنصاري، زين الدين أبو يحيى السنيكي (المتوفى: جبوهـ)، طا، دار الكتب العلمية - بيروت،

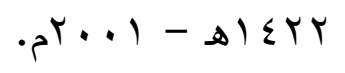

• الأم، الثافعي أبو عبد الله محمد بن إدريس بن العباس بن عثمان بن شافع بن عبد المطلب بن عبد مناف المطلبي القرشي المكي (المنوفى: ع. זهـ)،

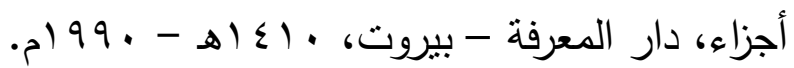
• الإنصاف في معرفة الراجح من الخلاف على مذهب الإمام أحمد - علاء الدين أبي علي بن سليمان بن أحمد المرداوي - دار الكتب العلمية - بيروت من -

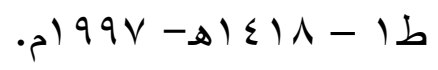

• بدائع الصنائع ترتيب الثرائع، الكاساني، علاء الدين، أبو بكر بن مسعود بن

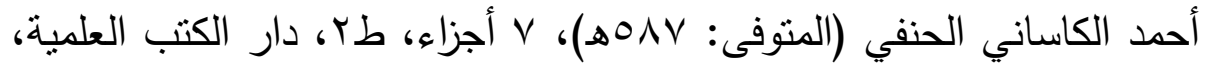

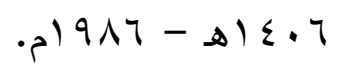

• التاج والإكليل لمختصر خليل، المواق، محمد بن يوسف بن أبي القاسم بن يوسف العبدري الغرناطي، أبو عبد الله المواق المالكي (المتوفى: لو^هـ)،

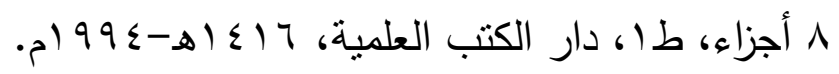




\section{نثوز الزوجة}

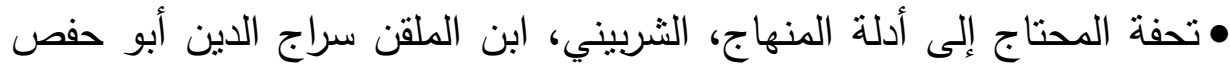

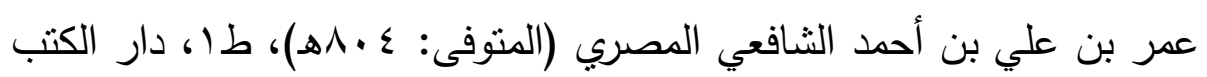

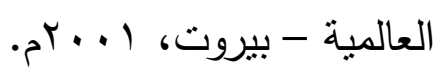

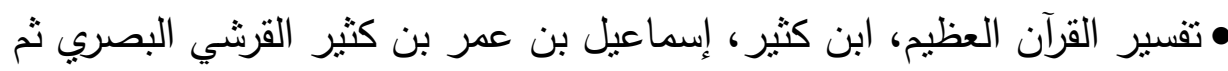

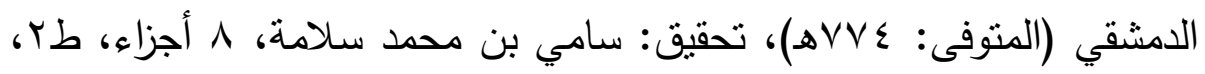

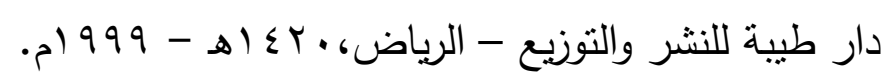

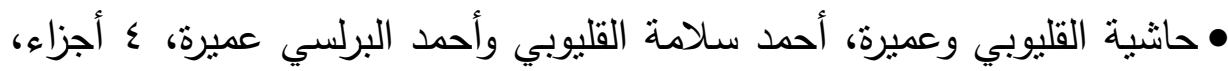

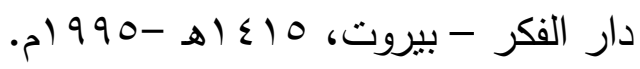
• الجامع لأحكام القرآن، القرطبي، محمد بن أحمد بن أبي بكر بن فرح الأنصاري

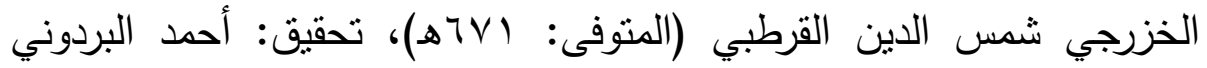

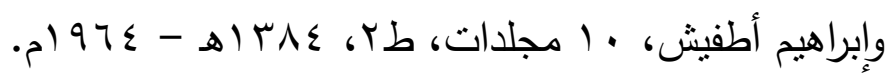

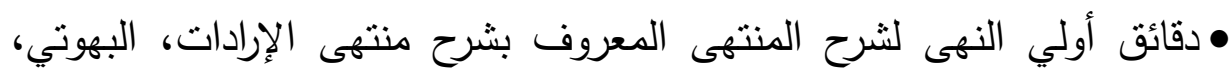

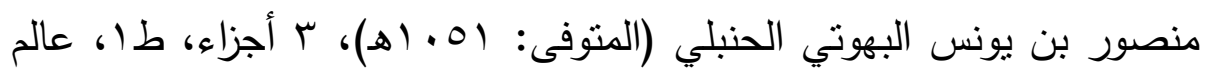

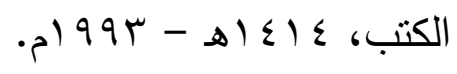
•رد المحتار على الدر المختار، ابن عابدين، محمد أمين بن عمر بن عبد إمباء

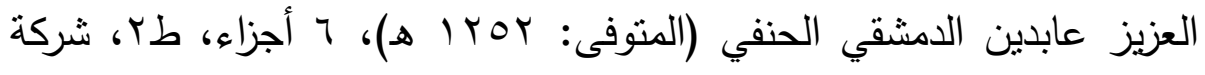
مكتبة ومطبعة مصطفى البابي الحلبي وأولاده بمصر (وصورتها دار الفكر -

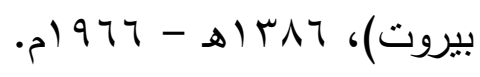
• سمو النتريع الإسلامي في معالجة النشوز والثنقاق بين الزوجين، كوثر كامل علي، دار الاعتصام، القاهرة.

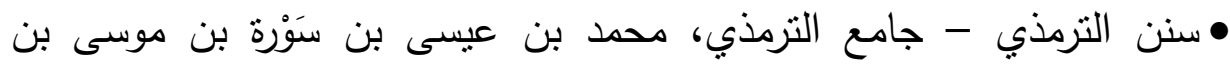

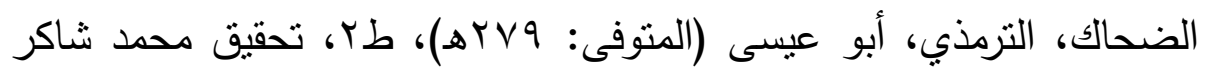




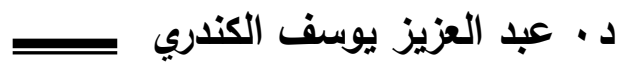

ومحمد فؤاد عبد الباقي، إبراهيم عطوة، ه أجزاء، طب، شركة مكتبة ومطبعة

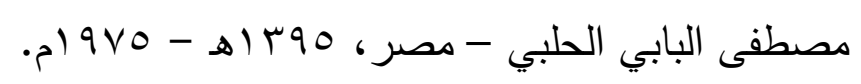

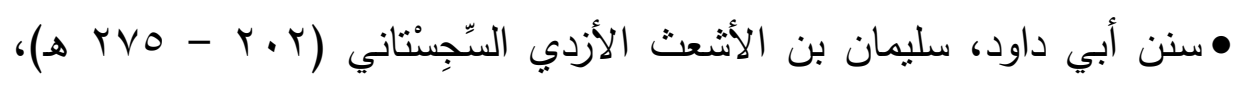
تحقيق: شعَبب الأرنؤوط - محَمَّد كامِل قره بللي، V أجزاء، طاه له دار الرسالة

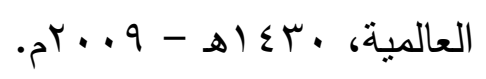

•شرح مختصر خليل للخرشي، محمد بن عبد الله الخرشي المالكي أبو عبد الله

$$
\text { (المتوفى: 1 إ (اهـ)، م أجزاء، دار الفكر - بيروت. }
$$

•صحيح البخاري - الجامع المسند الصحيح المختصر من أمور رسول الله صلى الله عليه وسلم - وسننه وأيامه، البخاري، طا، 9 أجزاء، دار طوق النجاة (مصورة عن السلطانية بإضافة نرقيم محمد فؤاد عبد الباقي)، بr أهـ

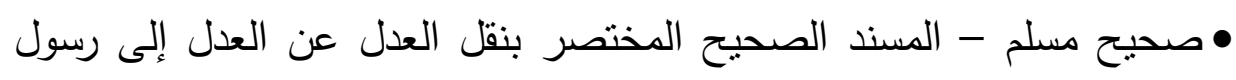
الله - صلى الله عليه وسلم - مسلم بن الحجاج أبو الحسن القتثيري النيسابوري (المتوفى: ابrهـ)، تحقيق محمد فؤاد عبد الباقي، 0 أجزاء، دار إحياء التراث

$$
\text { العربي - بيروت. - مات. }
$$

• الفروع، ابن مفلح، محمد بن مفلح بن محمد بن مفرج، أبو عبد الله، شمس الدين المقدي الرامينى ثم الصالحي الحنبلي (المتوفى: سجレهـ)، تحقيق عبد

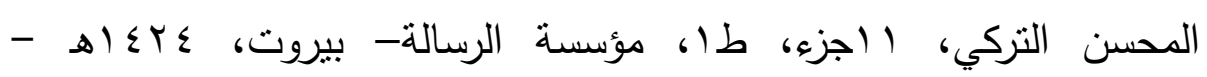

r . . ب م. ومعه تصحيح الفروع لعلاء الدين علي بن سليمان المرداوي.

• قانون الأحوال الثخصية الكويتي - الفتوى والتشريع - مجلس الوزراء -

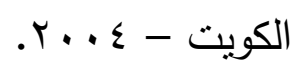

• كثاف القناع عن منن الإقناع، البهوتي، منصور بن يونس البهوتي الحنبلي (المتوفى: 01 ـ (هـ)، 7 أجزاء، دار الكتب العلمية. 
• لسان العرب، ابن منظور، محمد بن مكرم بن على ابن منظور الأنصاري

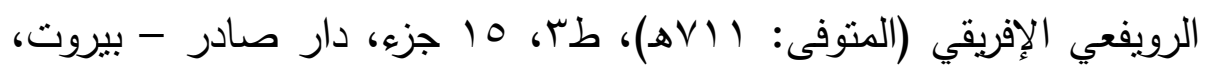

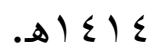

• المبسوط، السرخسي، محمد بن أحمد بن أبي سهل شمس الأئمة السرخسي

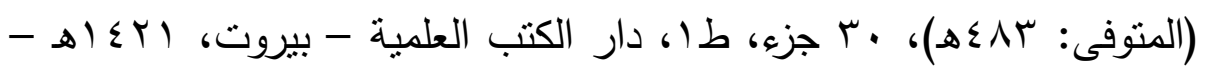

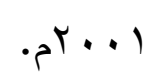

• المحلى بالآثار، أبو محمد علي بن أحمد بن سعيد بن حزم الأندلسي القرطبي

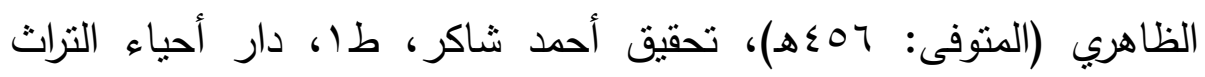

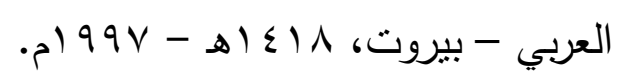

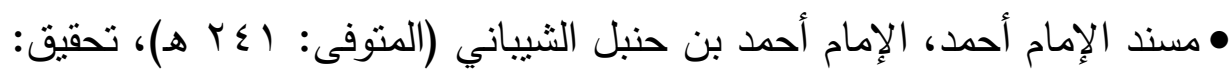

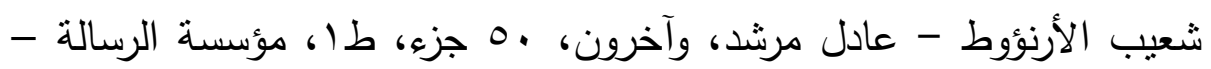

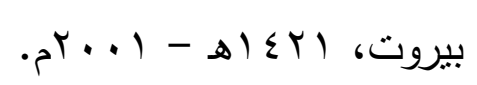

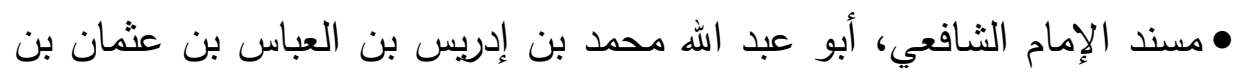

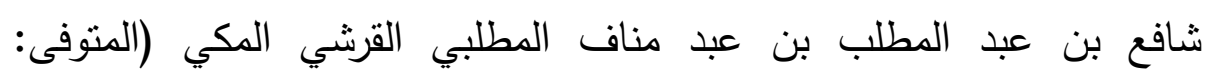

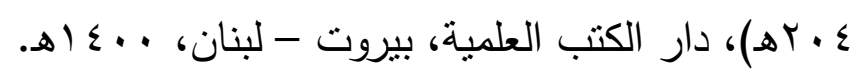

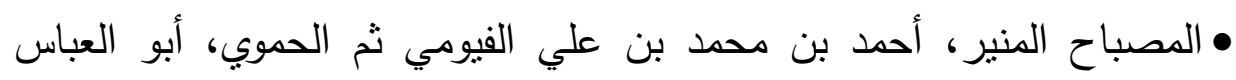

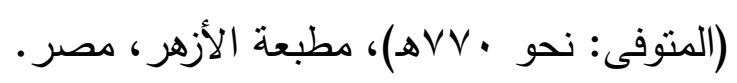

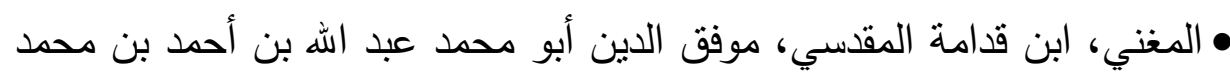
بن قدامة المقدي الجماعيلي الدمشقي الصالحي الحنبلي (المتوفى: •.بآهـ)،

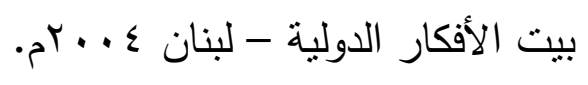

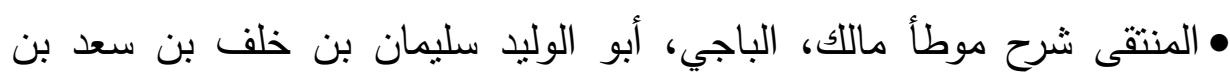

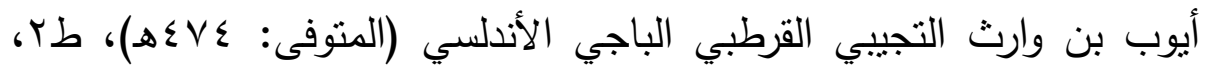

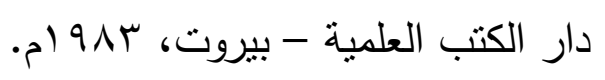




\section{دـ · · عبد العزيز يوسف الكندري}

• منح الجليل شرح مختصر خليل، عليش، محمد بن أحمد بن محمد عليش، أبو

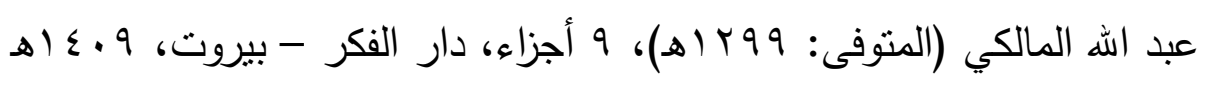

$$
\text { . }) 919-
$$

• مواهب الجليل شرح مختصر خليل، الحطاب، محمد بن محمد بن عبد الرحمن الطرابلسي المغربي، المعروف بالحطاب الرُّعيني المالكي (المتوفى: ـ00هـ).

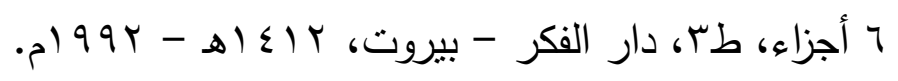

• الموسوعة الفقهية، وزارة الأوقاف و الثؤون الإسلامية، الكويت، 0 ــ جزءاً،

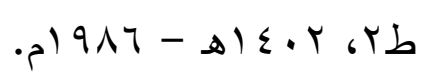

• نشوز الزوجة أسبابه وعلاجه في الفقه الإسلامي، علي محمد قاسم، دار

$$
\text { الجامعة الجديدة للنشر - الإسكندرية - ع . . ب م. }
$$

• نهاية المحتاج إلى شرح المنهاج، الرملي، شمس الدين محمد بن أبي العباس الإله أحمد بن حمزة شهاب الدين الرملي (المتوفى: ع ـ . اهـ)، 1 أجزاء، دار الفكر

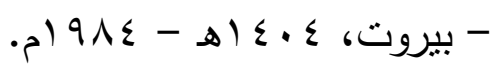

